\title{
Legal safeguards against involuntary criminal confessions in Poland and Russia
}

\author{
Garantias legais contra confissões criminais \\ coagidas na Polônia e na Rússia
}

\author{
Denis Solodov ${ }^{1}$ \\ Department of Criminology and Criminalistics, \\ University of Warmia and Mazury in Olsztyn, Poland \\ denis.solodov@uwm.edu.pl \\ http://orcid.org/0000-0003-2884-9420 \\ Ilia Solodov ${ }^{2}$ \\ Voronezh Bar Association, Russian Federation \\ badanie.etyka@gmail.com \\ http://orcid.org/0000-0002-8677-2559
}

\begin{abstract}
AвSTRACT: Criminal confession is a powerful and highly incriminating piece of evidence. An authentic inculpatory confession can be a fertile source of new evidence known only to the actual perpetrator. It helps the prosecution to build a stronger case against the defendant in a situation where only circumstantial evidence is available. In some cases, such as no-body homicides and wild-land arson fires, it is difficult to prove the defendant's participation and guilt without his willing and full cooperation. All of this explains why in the era of advanced forensic techniques criminal investigators are keen to obtain confessions using a variety of tactics. Studies show, however, that some interrogation techniques are more likely to induce false confessions, which, in turn, increase the likelihood of judicial errors. From a human rights perspective, the European Court of Human Rights has expressed serious
\end{abstract}

1 PhD with habilitation, associate professor. Department of Criminology and Criminalistics, University of Warmia and Mazury in Olsztyn, Poland.

2 PhD, advocate, Voronezh Bar Association, Russian Federation. 
concerns about the use of evidence obtained through violence, coercion or torture but has been unable to establish the balance between efficient law enforcement and adequate protection of individual rights. In the article, legal provisions against improper police compulsion in Poland and Russia were analyzed. It appears that each country applies a different approach to the issue of police coercion. In Russia, the law provides specific rules on the admissibility of criminal confessions, their evidentiary value, and methods of verifying the reliability of suspect's testimony. In Poland, the law confers a wider discretion on the domestic courts as to how to deal with confession evidence and the allegations concerning the use of coercive interrogation techniques. Based on the results of the analysis of pertinent legal provisions, case-law and legal doctrine, the authors aimed to determine the effectiveness of two models in preventing and dealing with coerced criminal confessions. Several changes were suggested to address the issue of excessive judicial formalism concerning the allegations regarding the use of unlawful interrogation techniques.

KeYwords: criminal proceedings; the right to a fair trial; criminal confessions; police coercion; admissibility of evidence.

Resumo: A confissão criminal é uma prova poderosa e altamente incriminadora. Uma confissão autoincriminatória autêntica pode ser uma fonte produtiva de novas provas conhecidas apenas pelo verdadeiro autor do crime. Ela também ajuda a acusação a construir um caso mais forte contra o réu em uma situação em que apenas indícios estão disponíveis. Em alguns casos, como homicídios sem localização do corpo e incêndios criminosos em terras selvagens, é difícil provar a participação e a culpa do réu sem o seu consentimento e total cooperação. Tudo isso explica por que, na era das técnicas forenses avançadas, os investigadores buscam obter confissões usando uma variedade de estratégias. Estudos mostram, entretanto, que algumas técnicas de interrogatório têm maior probabilidade de induzir falsas confissões, o que, por sua vez, potencializa o risco de erros judiciais. Do ponto de vista dos direitos humanos, o Tribunal Europeu de Direitos Humanos expressou sérias preocupações sobre o uso de provas obtidas por meio de violência, coerção ou tortura, mas não estabeleceu um equilíbrio entre a aplicação eficaz da lei penal e a proteção adequada dos direitos individuais. Neste artigo, analisam-se as disposições legais contra a compulsão policial imprópria na Polônia e na Rússia. Afirma-se que cada país adota uma perspectiva diferente sobre a questão da coerção policial. Na Rússia, a lei 
fornece regras específicas sobre a admissibilidade de confissões criminais, seu valor probatório e métodos de verificação da confiabilidade do depoimento do suspeito. Na Polônia, a lei confere aos tribunais nacionais uma maior discricionariedade quanto ao modo de lidar com a confissão e as alegações em relação à utilização de técnicas de interrogatório coercivas. Com base nos resultados da análise de dispositivos legais pertinentes, jurisprudência e revisão bibliográfica, nesta pesquisa busca-se determinar a eficácia de dois modelos jurídicos na prevenção e tratamento de confissões penais coagidas. Em sede proporsitica, alterações foram sugeridas para abordar a questão do formalismo judicial excessivo em relação às alegações sobre o uso de técnicas de interrogatório ilegais.

Palavras-chave: processo penal; direito ao justo processo; confissões criminais; coerção policial; admissibilidade da prova.

SUMMARY: 1. Introduction. 2. Legal principles regarding improper police compulsion in international and European law. 3. Legal safeguards against coerced criminal confessions in Poland. 4. Legal safeguards against coerced criminal confessions in the Russian Federation. 5. Discussion. Conclusions; References.

\section{INTRODUCTION}

The issue of involuntary criminal confessions is a complex one and can be addressed on different levels including legal, administrative, psychological, and forensic. There have been many publications concerning the psychology of confessions, which provide some valuable insights ${ }^{3}$. Researchers are drawing attention to the fact that a confession is the most powerful piece of evidence the prosecution might possess principally because it appears very unlikely that anyone would willingly confess to

3 GUDJONSSON, Gisli H. The Psychology of Interrogations and Confessions: A handbook. Chichester: John Wiley \& Sons Ltd, 2003; KASSIN, Saul M.; GUDJONSSON, Gisli H. The Psychology of Confessions: A Review of the Literature and Issues. Psychological Science in the Public Interest, v. 5, n. 2, p. 33-67, 2004; RUSSANO, Melissa B.; MEISSNER, Christian A.; NARCHET, Fadia M.; KASSIN, Saul M. Investigating True and False Confessions Within a Novel Experimental Paradigm. Psychological Science, n. 16(6), p. 481-486, 2015. 
a crime he or she did not commit ${ }^{4}$. Suspect's confession can be a fertile source of new evidence, especially the one known only to the actual perpetrator. It also helps to build a stronger case against the defendant in a situation where there is only circumstantial evidence. In some criminal cases, such as no-body homicides and wild-land arsons, it is extremely difficult to prove the defendant's participation and guilt without his willing full cooperation. Not surprisingly, in the era of advanced forensic techniques, police officers are still keen to obtain suspect's confession or other incriminating statements from those suspected of committing criminal offences ${ }^{5}$. To achieve this goal, a variety of tactics is being used, some of them highly controversial and some even illegal. Interestingly, the problem of unlawful duress appears to affect not only the developing countries but most western states as well ${ }^{6}$.

It should be noted that the prohibition of torture, inhuman or degrading treatment is a bedrock principle of international law. The majority of the world's countries have ratified the United Nation's Convention against Torture and Other Cruel, Inhuman or Degrading Treatment or Punishment of 10 December 1984. In Europe, the European Court of Human Rights has developed an impressive body of the case-law concerning the issue of improper police compulsion. Following the wording of Article 6 of the European Convention on Human Rights, the Court, although not in the expressed terms, obliges all member states to adopt legal safeguards against improper police compulsion, including exclusionary rules ${ }^{7}$. Besides, some member states

4 RASSIN, Eric; ISRAËLS, Han. False confessions in the lab: a review. Erasmus Law Review, v. 7, n. 4, p. 219, 2014.

5 MOSCATELLI, Lívia Yuen Ngan. Considerações sobre a confssão e o método Reid aplicado na investgação criminal. Revista Brasileira de Direito Processual Penal, v. 6, n. 1, p. 368, 2020; MCCONVILLE, Michael; BALDWIN, John. The role of interrogation in crime discovery and conviction. The British Journal of Criminology, v. 22, n. 2, p. 165, 1982; GUDJONSSON, Gisli H.; PEARSE, John. Suspect Interviews and False Confessions. Current Directions in Psychological Science, v. 20, n. 1, p. 33-34, 2011.

6 Human Rights Watch. World Report 2020, Available at: <https://www.hrw. org/sites/default/files/world_report_download/hrw_world_report_2020_0. pdf >. Access on: September 10, 2020.

7 In this article the terms "police coercion" and "improper police impulsion" are used as umbrella terms covering physical torture or other forms of 
have incorporated some of the pertinent forensic recommendations into domestic law. In Russia, for example, a special investigative procedure called "verification of the evidence on the spot" was introduced in 2001. The law also limits the length of interrogations forcing the interrogators to take regular breaks. In the Polish law of criminal procedure, it is forbidden to substitute the testimony of the accused by the contents of documents or notes - the rule, which ensures the priority of firsthand, direct evidence ${ }^{8}$.

In this article, we analysed legal principles and restrictions regarding involuntary testimony in two European countries - Poland and Russia. Each country appears to apply a different approach to the issue of police coercion. In Russia, the law of criminal procedure limits judicial discretion in this area by providing detailed rules concerning police interrogations, the verification of confession statements and even the evidentiary value of criminal confessions. In Poland, courts have wider discretion regarding this type of evidence, including the handling of the claims regarding improper police compulsion. However, in both countries, there have been known cases of police misconduct concerning not only crimes but also petty offences.

The aim of the article was to determine whether the existing legal protections could provide an effective remedy to the problem of improper police compulsion and whether these legal provisions are properly implemented and enforced. Based on this aim, we stated the research question as follows:

- what is the general attitude toward improper police compulsion in international and European law?

- what kinds of legal safeguards are in place to protect individuals from improper police compulsion in Poland and Russia? How these legal provisions are implemented and complied with in practice?

improper compulsion used by the key "players" of the lowest level of the criminal justice system, such as police officers and law enforcement personal of other investigative agencies, to obtain criminal confessions and other incriminating statements.

8 KUCHARCZYK, Mariusz. Zakaz substytuowania dowodu z wyjaśnień oskarżonego treścią pism, zapisków i notatek urzędowych. Prokuratura i Prawo, n. 5 , p. $147-148,2005$. 
- what should be done to improve protection against improper police compulsion from the legal side?

The observations and conclusions presented in the article were based on the analysis of relevant legal provisions, case-law and legal doctrine, as well as the authors' own professional experience as defence attorneys. So, in drawing conclusions and proposing legal changes, the authors were aware of the fact that their judgements might have been somewhat biased.

\section{LEGAL PRINCIPLES REGARDING IMPROPER POLICE COMPULSION IN INTERNATIONAL AND EUROPEAN LAW}

The issue of improper police compulsion has been part of a perennial debate on the complex relations between human rights and police investigative efficiency for many years. Pertinent legal standards were set in 1948 by the United Nations' Universal Declaration of Human Rights ${ }^{9}$, the European Convention on Human Rights and Fundamental Freedoms (1950) ${ }^{10}$ and later specified in the Convention against Torture and Other Cruel, Inhuman or Degrading Treatment or Punishment adopted by the United Nations General Assembly on 10 December 1984 (Resolution 39/46) ${ }^{11}$.

Although the Universal Declaration of Human Rights is not a binding international treaty, all states are bound to respect its provisions. Article 5 of the Universal Declaration expressly prohibits the use of torture or cruel, inhuman or degrading treatment to obtain either information or a confession. It does not, however, specify the

9 Universal Declaration of Human Rights of 1948. Available at: <https://www. un.org/en/universal-declaration-human-rights/>. Access on: September $10,2020$.

10 European Convention on Human Rights and Fundamental Freedoms of 1950, Available at: <https://www.echr.coe.int/Documents/Convention_ENG. pdf $>$. Access on: September 10, 2020.

11 Convention against Torture and Other Cruel, Inhuman or Degrading Treatment or Punishment of 1984, Available at: < https://treaties.un.org/doc/ Treaties/1987/06/19870626\%2002-38\%20AM/Ch_IV_9p.pdf >. Access on: September 10, 2020. 
behaviour that constitutes torture. The definition of torture can be found in Article 1 of the Convention against Torture of 1984, which provides that the term "torture" means "any act by which severe pain or suffering, whether physical or mental, is intentionally inflicted on a person for such purposes as obtaining from him or a third person information or a confession, punishing him for an act he or a third person has committed or is suspected of having committed, or intimidating or coercing him or a third person, or for any reason based on discrimination of any kind, when such pain or suffering is inflicted by or at the instigation of or with the consent or acquiescence of a public official or other person acting in an official capacity". It does not, however, include pain or suffering arising only from, inherent in or incidental to lawful sanctions. The Convention against Torture obliges all states to ensure that "any statement which is established to have been made as a result of torture shall not be invoked as evidence in any proceedings, except against a person accused of torture as evidence that the statement was made" (Article 15 of the Convention against Torture).

The European Convention on Human Rights addresses the issue of improper police compulsion in several articles: Article 3 - Prohibition of torture, Article 5 - Right to liberty and security, and Article 6 - Right to a fair trial. In its applicable jurisprudence, the European Court emphasizes that the right to remain silent when being questioned by the police and the privilege against self-incrimination are recognised international standards laying "at the heart of the notion of a fair procedure under Article 6". "By providing the accused with protection against improper compulsion by the authorities these immunities contribute to avoiding miscarriages of justice and to securing the aims of Article 6"12. In a milestone case of Gäfgen v. Germany, the Court held that "even in the most difficult circumstances, such as the fight against terrorism and organised crime, the Convention prohibits in absolute terms torture and inhuman or degrading treatment or

12 European Court of Human Rights. Judgement of the Grand Chamber in the case of John Murray v. the United Kingdom of 8 February 1996. Application no. 18731/91. Available at: <https://hudoc.echr.coe.int/eng\#\{\%22dmdocnumber\%22:[\%22695857\%22],\%22itemid\%22:[\%22001-57980\%22]\}>. Access on: September 10, 2020. 
punishment, irrespective of the conduct of the person concerned"13. This restriction, however, does not necessarily extend to the evidence derived from evidence obtained by torture, inhuman or degrading treatment. Despite the Court has condemned the use of such evidence, their use is allowed if they are not crucial for the case $\mathrm{e}^{14}$.

In the context of improper police compulsion, the Court repeatedly highlights the importance of the right to legal assistance. In several landmark decisions, i.e. Salduz v. Ibrahim and Others ${ }^{15}$, Simeonovi v. Bulgaria ${ }^{16}$, the Court stated that prompt access to a lawyer is a fundamental guarantee against coercion and ill-treatment of suspects by the police during custodial interrogations. As a general rule, each suspect should be granted access to legal assistance from the moment there is a "criminal charge" against him within the meaning of the Convention. The Court stressed out that "a person acquires the status of a suspect calling for the application of the Article 6 safeguards not when that status is formally assigned to him or her, but when the domestic authorities have plausible reasons for suspecting that person's involvement in a criminal offence" ${ }^{17}$.

Nevertheless, in certain exceptional situations the access to a lawyer can be restricted. These restrictions must be temporary and justified

13 European Court of Human Rights. Judgement of the Grand Chamber in the case of Gäfgen v. Germany of 1 June 2010. Application no. 22978/05. Available at: < https://hudoc.echr.coe.int/tur\#\{\%22itemid\%22:[\%22001-99015\%22]\} >. Access on: September 10, 2020.

14 WĄSEK-WIADEREK, Małgorzata. Przegląd orzecznictwa Europejskiego dotyczącego spraw karnych. Zeszyt, n. 1-2, p.21, 2010.

15 European Court of Human Rights. Judgement in the case of Ibrahim and others v. the United Kingdom of 16 December 2014. Applications nos. 50541/08, 50571/08, 50573/08 and 40351/09. Available at: < http://hudoc. echr.coe.int/fre?i=001-148676>. Access on: September 10, 2020.

16 European Court of Human Rights. Judgement of the Grand Chamber in the case of Simeonovi v. Bulgaria of 12 May 2017. Application no. 21980/04. Available at: < http://hudoc.echr.coe.int/eng?i=001-172963>. Access on: September 10, 2020.

17 European Court of Human Rights. Guide on Article 6 of the European Convention on Human Rights Right to a fair trial (criminal limb). Updated on 30 April 2020, p. 75. Available at: <https://www.echr.coe.int/Documents/ Guide_Art_6_criminal_ENG.pdf >. Access on: September 10, 2020. 
by the circumstances of the case. In the case of Beuze v. Belgium ${ }^{18}$ the Court's rhetoric slightly changed. The Court expressed an opinion that the restriction of the right of access to a lawyer during the first police interrogation without compelling reasons could be counter-balanced by other legal safeguards, thus, the fairness of the trial could be, nonetheless, preserved. Some commentators suggest that by exalting the restrictions of the right to legal assistance, the Court has created better conditions for the police and other law enforcement agencies at the crucial initial stage of criminal proceedings ${ }^{19}$. The Court's later judgements demonstrate, however, that it does not depart from the earlier established line of precedent concerning the issue of improper police compulsion. In the Court's opinion, the use of statements obtained following a violation of Article 3 of the Convention automatically deprives the proceedings of fairness and violates Article 6 . This rule applies both to self-incriminating statements made by the accused and to witness statements obtained in violation of Article $3^{20}$.

Based on the corresponding case-law, the Court identifies three forms of improper police compulsion:

1. a person testified under a threat of sanctions or was sanctioned for refusing to testify;

18 European Court of Human Rights. Judgement of the Grand Chamber in the case of Beuze v. Belgium of 9 November 2018. Application no. 71409/10. Available at: < http://hudoc.echr.coe.int/eng?i=001-187802>. Access on: September 10, 2020.

19 HODGSON, J. The Challenge of Universal Norms: Securing Effective Defence Rights Across Different Jurisdictions and Legal Cultures. Journal of Law and Society, 46, p. 95-114, 2019; EECHAUDT, V., CLAEYS, J., BEKEN, T. V.; CIUFFOLETTI, S.; HUGUES DE SUREMAIN, RANAL, D. Research project EUPRETRIALRIGHTS Improving the protection of fundamental rights and access to legal aid for remand prisoners in the European Union. Analysis of European law as regard to access of detained persons to the law and to court. Available at: <https://biblio.ugent.be/publication/8625571/file/8625572>. Access on: September 10, 2020.

20 European Court of Human Rights. Judgement in the case of Affaire Urazbayev v. Russia of 8 October 2019. Application no. 13128/06. Available at: <http:// hudoc.echr.coe.int/eng?i=001-196408>. Access on: September 10, 2020; European Court of Human Rights. Judgement in the case of case of Almaši v. Serbia of 8 October 2019. Application no. 21388/15. Available at: <http:// hudoc.echr.coe.int/eng?i=001-196417>. Access on: September 10, 2020. 
2. physical or psychological pressure was applied to obtain material evidence or statements

3. subterfuge was used by the authorities to elicit information that they were unable to obtain during questioning ${ }^{21}$.

It should be noted that this classification generally coincides with the situational factors associated with coerced criminal confessions ${ }^{22}$.

Concerning the admissibility of illegally obtained evidence, the Court emphasizes its subsidiary role pointing to the fact that the Convention does not lay down any rules on this issue. The Court, however, repeatedly stresses the importance of the overall fairness of the trial, which, in the opinion of the Court, should be assessed in the light of the following factors:

- whether the defence was allowed to challenge the authenticity of the evidence and to oppose its use;

- the quality of the evidence in question, as well as the circumstances in which it was obtained and whether these circumstances cast doubt on its reliability or accuracy;

- circumstances in which it was obtained and its reliability or accuracy;

- whether the evidence in question was or was not decisive for the outcome of the criminal proceedings ${ }^{23}$.

21 European Court of Human Rights. Guide on Article 6 of the European Convention on Human Rights

Right to a fair trial (criminal limb). Updated on 30 April 2020, p. 36. Available at: <https://www.echr.coe.int/Documents/Guide_Art_6_criminal_ENG. pdf>. Access on: September 10, 2020.

22 KASSIN, S. M.; DRIZIN, S. A.; GRISSO, T.; GUDJONSSON, G. H.; LEO, R. A.; REDLICH, A. D. Police-Induced Confessions: Risk Factors and Recommendations. Law and Human Behaviour, n. 34, p. 16-19, 2010; LEO, R. Police Interrogations, False Confessions, and Alleged Child Abuse Cases. University of Michigan Journal of Law Reform, n. 50, p. 710-714, 2017.

23 European Court of Human Rights. Guide on Article 6 of the European Convention on Human Rights Right to a fair trial (criminal limb). Updated on 30 April 2020, p. 38-39. Available at: <https://www.echr.coe.int/Documents/ Guide_Art_6_criminal_ENG.pdf $>$. Access on: September 10, 2020; RUDICH, V.V. Standarty dopustimosti dokazatel'stv po ugolovnym delam, vyrabotannye v reshenijah Evropejskogo suda po pravam cheloveka. Mezhdunarodnoe ugolovnoe pravo i mezhdunarodnaja justicija, n. 5, p. 9 - 12, 2017. 
The Court generally differentiates two types of cases: the ones, where the infringements of the rights protected by the Convention could be "repaired" and the ones, where such infringements are "unrepairable" concerning, for example, the use of torture or other inhumane treatment (Article 3 of the Convention) or the deprivation of legal assistance. In the case of El Haski v. Belgium ${ }^{24}$, the Court found that the impugned statements later used against the applicant had been obtained in Morocco using treatment prohibited by Article 3 of the Convention. According to the Court, the domestic courts were required not to admit them in evidence unless they had first verified, that they had not been obtained in such manner. In its judgement, the Court once again underlined the significance of the guarantee provided for in Article 3 holding that irrespective of the kind of ill-treatment whether it is torture, inhuman or degrading treatment the proceedings as a whole become automatically unfair. The Court expressed the opinion that this is also true in the case, where the prosecution uses real evidence obtained as a direct result of torture or inhuman treatment regardless of whether such evidence was decisive for the outcome of the proceedings. It would be unfair to impose on the applicant a burden of proof that went beyond the demonstration of a "real risk" that the evidence in question had been obtained in breach of Article 3 of the Convention. The Court also paid attention to the fact that the allegations of torture are often difficult to prove since it is practised in secret by experienced interrogators who were skilled at ensuring that it left no visible signs on the victim. "All too frequently, those who were charged with ensuring that torture did not occur - courts, prosecutors and medical personnel - were complicit in its concealment". "In a criminal justice system where the courts were independent of the executive, where cases were prosecuted impartially, and where allegations of torture were conscientiously investigated, one might conceivably require a defendant to prove to a high standard that the evidence against him had been obtained by torture. However, in a criminal justice system which was complicit in

24 European Court of Human Rights. Judgement in the case of El Haski v. Belgium of 25 September 2012. Application no. 649/08. Available at: <https:// hudoc.echr.coe.int/fre\#\{\%22itemid\%22:[\%22001-113445\%22]\}>. Access on: September 10, 2020. 
the very practices which it existed to prevent, such a standard of proof, was wholly inappropriate" (§ 86).

In our opinion, these interpretations require the adoption of effective legal mechanisms to enhance the judicial response to the allegations concerning the use of torture or other unlawful investigative techniques.

It should be noted that in our analysis of European law, we intentionally omitted several directives directly or indirectly related to the issue, such as the Directive 2012/13/EU of 22 May 2012 on the right to information in criminal proceedings ${ }^{25}$, the Directive 2013/48/ EU of 22 October 2013 on the right of access to a lawyer in criminal proceedings $^{26}$, the Directive (EU) 2016/1919 of 26 October 2016 on legal aid for suspects and accused persons in criminal proceedings, the Directive (EU) 2016/343 of the European Parliament and of the Council of 9 March 2016 on the strengthening of certain aspects of the presumption of innocence and of the right to be present at the trial in criminal proceedings ${ }^{27}$, the Directive (EU) 2016/800 of 11 May 2016 on procedural safeguards for children who are suspects or accused persons in criminal proceedings ${ }^{28}$. Unlike Poland, the Russian Federation has not been part of those agreements. Besides, the abovementioned directives have been reportedly implemented

25 Directive 2012/13/EU of 22 May 2012 on the right to information in criminal proceedings. Available at: < https://eur-lex.europa.eu/legal-content/EN/ TXT/?uri=celex:32012L0013>. Access on: September 10, 2020.

26

Directive 2013/48/EU of 22 October 2013 on the right of access to a lawyer in criminal proceedings. Available at: <https://eur-lex.europa.eu/ legal-content/EN/TXT/?uri=celex\%3A32013L0048 >. Access on: September 10, 2020.

27 Directive (EU) 2016/343 of the European Parliament and of the Council of 9 March 2016 on the strengthening of certain aspects of the presumption of innocence and of the right to be present at the trial in criminal proceedings. Available at: <https://eur-lex.europa.eu/legal-content/EN/TXT/?uri=CELEX\%3A32016L0343>. Access on: September 10, 2020.

Directive (EU) 2016/800 of 11 May 2016 on procedural safeguards for children who are suspects or accused persons in criminal proceedings, Available at: < https://eur-lex.europa.eu/legal-content/EN/TXT/?uri=CELEX\%3A32016L0800>. Access on: September 10, 2020. 
by Poland ${ }^{29}$, so it may be assumed that the Polish law has already met their requirements.

\section{Legal SAfEguARds AgAinst COERCED CRIMINAL CONFESSIONS IN PolAND}

In the Polish law of criminal procedure, there are several legal provisions addressing the issue of improperly compelled testimony. Firstly, there are rules on the admissibility of evidence. Under Article 168a of the Polish Code of Criminal Procedure of $1997^{30}$ (CCP), a piece of evidence cannot be considered inadmissible solely on the basis that it was obtained in violation of the rules of the criminal procedure or through criminal offence unless the evidence in question was obtained by a public official as a result of a murder, intentional infliction of bodily harm or unlawful deprivation of liberty. Following the actual wording of this legal norm, evidence obtained in violation of procedural rules is admissible if such a violation is the only known defect.

It should be noted, however, that in the Polish legal doctrine and case-law the provisions of Article 168a CCP are being interpreted in extremely different ways. Some scholars suggest that the content of this article should be interpreted strictly, following its literal meaning. So, evidence obtained with a violation of the procedural rules or even through criminal offence should be admissible unless there is an indication that a public official committed murder, intentional infliction of bodily harm or unlawful deprivation of liberty ${ }^{31}$. Others believe that the content of Article 168a CCP must be interpreted broadly, in the context of other legal norms including the provisions regarding rights of the case participants

292019 Commission report on monitoring the application of EU law. Available at: < https://ec.europa.eu/info/publications/2019-commission-report-monitoring-application-eu-law_en >. Accessed on: September 10, 2020.

30 Code of Criminal Procedure of the Republic of Poland of 6 June 1997. Available at: <https://isap.sejm.gov.pl/isap.nsf/download.xsp/WDU19970890555/U/ D19970555Lj.pdf>. Access on: September 10, 2020.

31 BRZOZOWSKI, Sebastian. Dopuszczalność dowodu w kontekście regulacji art. 168a k.p.k. Przegląd Sądowy, n. 10, p. 60-74, 2016. 
and fundamental principles of the Polish law $^{32}$. Some researchers say that the provisions of Article 168a CCP are needed to be interpreted in the light of the Polish Constitution and European law. Evidence obtained with a violation of procedural rules would be inadmissible if a public official violates constitutional rights and guarantees ${ }^{33}$. In the Polish case-law, it is recognized that the provisions of Article 168a CCP should not be used as a way to give validity to illegally obtained evidence in a situation when procedural violations undermine the overall fairness of the proceedings in the light of Article 6 of the European Convention ${ }^{34}$. It should be noted that this opinion generally coincides with the abovementioned European Court's approach to the issue of unlawfully obtained criminal evidence.

In the Polish case law and legal doctrine, prevails an opinion that Article 168a CCP does not explicitly forbid the use of the evidence derived from illegally obtained evidence ${ }^{35}$. Some authors, however, are of opinion that derived evidence must be considered inadmissible unless it

32 JASIŃSKI, W. Rozdział 26. Zasady wykorzystywania dowodów. In: HOFMAŃSKI, P., SKORUPKA J. (editors). System Prawa Karnego Procesowego. Tom VIII: Dowody. Part 2, Warszawa: Lexis Nexis, p. 2675, 2019; JASIŃSKI, W. Racjonalna regulacja karnoprocesowej dopuszczalności dowodów uzyskanych z naruszeniem praw jednostki. Acta Universitatis Wratislaviensis, n. 3978, p. 87, 2020.

33 SKORUPKA, J. Prokonstytucyjna wykładnia przepisów prawa dowodowego w procesie karnym. In: GRZEGORCZYK, T.; OLSZEWSKI R. (editors). Verba volant, scripta manent. Proces karny, prawo karne skarbowe $i$ prawo wykroczeń po zmianach z lat 2015-2016. Księga pamiątkowa poświęcona Profesor Monice Zbrojewskiej, Warszawa: Wolters Kluwer, p. 360, 2016; BŁOŃSKI, M. Przeprowadzanie na rozprawie dowodów uzyskanych w ramach czynności operacyjno-rozpoznawczych. Prokuratura i prawo, n. 9, p.90, 2017; LIPIŃSKI, Konrad. Klauzula uadekwatniająca przesłanki niedopuszczalności dowodu w postępowaniu karnym (art. 168a k.p.k.). Prokuratura i Prawo, n. 11, p. 44-59, 2016.

34 Judgement of the Polish Supreme Court of 26 June 2019 in the case no. IV KK 328/18. Available at: <http://www.sn.pl/sites/orzecznictwo/Orzeczenia3/ IV\%20KK\%20328-18.pdf>. Access on: September 10, 2020.

35 Judgement of the District Court in Czestochowa of 8 May 2019 in the case no. VII Ka 58/19. Available at: < https://sip.lex.pl/orzeczenia-i-pisma-urzedowe/orzeczenia-sadow/vii-ka-58-19-wyrok-sadu-okregowego-w-czestochowie-522761214>. Access on: September 10, 2020; JASIŃSKI, W. Rozdział 26. Zasady wykorzystywania dowodów, p. 2726. 
was not decisive for the outcome of the proceedings and the defendant was allowed to challenge the authenticity of the evidence ${ }^{36}$.

Secondly, under \& 5 CCP, it is illegal to influence the statement of the questioned person through coercion or unlawful threat. Furthermore, the testimony obtained in this way cannot constitute proof (Article $171 \S 7$ CCP). In case law and legal doctrine, violations of this type are unanimously recognized as "unrepairable" 37 . For example, in the light of Article 171 \& 7 CCP, it would be illegal to interview the police officer about the content of suspect's testimony obtained in violation of Article 171 $\S 5 \mathrm{CCP}^{38}$. It also follows from settled case-law that the voluntariness of testimony must not be infringed ${ }^{39}$. There are, however, several contentious issues. First of all, the rule of Article $171 \& 7$ CCP refers only to procedural interrogations conducted under the provisions of CCP. Nonprocedural police questioning, which often precedes procedural interrogations falls outside the scope of this article. It should be noted that it is not required by law to accurately record the testimony provided by an interviewee. The result of the police questioning must be summarized in the note the police officer made afterwards. The interviewee cannot familiarize himself with the content of this note, raise objections or demand correcting its content. It is worth noting, however, that Polish courts, when dealing

36 SKORUPKA, J. Wykorzystanie w postępowaniu karnym dowodów bezpośrednio i pośrednio legalnych. In: GODYŃ, J.; HUDZIK, M.; PAPRZYCKI, L. K. (editors). Zagadnienia prawa dowodowego. Warszawa: Sąd Najwyższy, p. 29-30, 2011.

37 GABERLE, A. Dowody w sądowym procesie karnym, Kraków: Wolters Kluwer, p. 314, 2007; KMIECIK, R., Zakazy dowodowe - pojęcie i ich klasyfikacja. Skutki procesowe naruszenia zakazów, reguł i gwarancji procesowych w postępowaniu dowodowym. In: KMIECIK, R.(editor). Prawo dowodowe. Zarys wykładu, Warszawa: Wolters Kluwer, p. 215, 2008.

38 ŻBIKOWSKA, M. Dowód pośrednio nielegalny w polskim procesie karnym. Wojskowy Przegląd Prawniczy, n.1-2, p. 123, 2012.

39 Judgement of the Appellate Court in Warsaw of 9 October 2017 in the case no. II AKa 310/17. Available at: <https://sip.lex.pl/orzeczenia-i-pisma-urzedowe/orzeczenia-sadow/ii-aka-310-17-wplywanie-na-wypowiedzi-osoby-522498318>. Access on: September 10, 2020; Judgement of the Appellate Court in Gdansk of 22 June 2016 in the case no. II AKa 150/16. Available at: < https://sip.lex.pl/orzeczenia-i-pisma-urzedowe/orzeczenia-sadow/ii-aka-150-16-ustalanie-przez-sad-prawidlowosci-522177843>. Access on: September 10, 2020. 
with the allegations concerning improperly compelled testimony, often analyse the circumstances of the preceding police questioning ${ }^{40}$.

Besides, it appears that Article $171 \S 7$ CCP does not cover the behaviour of third parties. The information obtained by a private citizen through torture or another form of unlawful duress falls outside the scope of Articles 168a and $171 \S 7$ CCP. It could be, therefore, used as evidence regardless of its reliability ${ }^{41}$.

Another shortcoming relates to the way the defendants' claims regarding the use of improper interrogation techniques are being addressed by Polish courts. The response to the allegations concerning police coercion is often too formal. After interrogating the claimant, the court often refers the issue to the public prosecutor, who conducts an internal investigation and draws an official report. Since there are usually no physical traces of police misconduct, the investigation usually concentrates on testimonial evidence, which in such cases could be corrupted and highly unreliable. Part of the problem is that such claims are often regarded as a defence strategy aiming to raise doubts about the prosecution case, especially in the situations where the defendant previously confessed either fully or partially. With this in view, courts usually set an inadequately high standard of proof. Besides, the burden of proof in such cases is often incorrectly placed on the claimant instead on the side of the prosecution. Only a few cases where courts faced this type of claims have been publicized so $\mathrm{far}^{42}$. However, this highly questionable procedure of handling the allegations of police misconduct has never been officially criticized by the Polish higher-tier tribunals. Therefore, it may be assumed that this inefficient way of handling such claims is known and silently approved.

40 Judgement of the Polish Supreme Court of 9 October 2019 in the case no. II KK 500/18. Available at: < https://sip.lex.pl/orzeczenia-i-pisma-urzedowe/orzeczenia-sadow/v-kk-500-18-postanowienie-sadu-najwyzszego-523102815>. Access on: September 10, 2020.; Judgement of the Appellate Court in Poznan of 17 June 2014 in the case no. II AKa 107/14. Available at: <https://sip.lex.pl/orzeczenia-i-pisma-urzedowe/orzeczenia-sadow/ii-aka107-14-prowadzenie-przed-przesluchaniem-rozmowy-521587565 >. Access on: September 10, 2020.

41 JAŚIŃSKI, W. Rozdział 26. Zakazy wykorzystywania dowodów, p. 2605.

42 Judgement of the Appellate Court in Poznan of 17 June 2014 in the case no. II AKa 107/14. 
The relation between Article 168a and Article 171 \& 7 CCP is another intensely discussed topic. W. Jasiński concludes that the provisions of Article $171 \& 7$ CCP should be treated as lex specialis prevailing over the rules of Article $168 \mathrm{a} \mathrm{CCP}^{43}$. Other scholars suggest, however, that within the current legal framework the provisions of Article 168a CCP could be interpreted in such a way that they overweight the provisions of Article 171 CCP. Therefore, these authors argue that there is a risk that the evidence obtained with procedural including the ones provided for in Article 171 CCP would be allowed to use in a trial $^{44}$. It is worth noting that the possibility of this misinterpretation of Article 168a CCP was the subject of the complaint of the Polish Ombudsman addressed to the Constitutional Court in $2016^{45}$. It was, however, later withdrawn on the ground of illegitimacy of the Court's current composition.

Thirdly, as defined in Article 174 CCP, the contents of documents and notes shall not be substituted as evidence for the explanations of the accused or the testimony of witnesses. This is an important guarantee of the defendant's right to remain silent and safeguard against the substitution of his or her direct testimony. It should be noted, however, that such documents may be used as a source of information about the new evidence. Besides, it is not uncommon for criminal suspects to confess to friends, family members or medical personal. Their testimony can be later used as evidence against the defendant. It must also be noted that the rule of Article $174 \S 7$ CCP applies only to the testimony obtained in the course of procedural interrogations. So, for example, the testimony of the police officers who executed an arrest warrant about the defendant's alleged admissions would be admissible. The testimony

43 JASIŃSKI, W. Rozdział 26. Zakazy wykorzystywania dowodów, p. 2673.

44 GORA, Ł. Aksjologia procesowa a dopuszczalność dowodu z art. 168a k.p.k. Państwo i Prawo, n. 10, p. 121-132, 2018; GRUZA, Ewa; GOC, Mieczysław, MOSZCZYNSKI, Jarosław. Kryminalistyka, czyli o współczesnych metodach dowodzenia przestępstw. Zagadnienia prawne. Warsaw: Wolters Kluwer, p. 83, 2020.

45 Appeal of the Polish Ombudsman regarding Article 168a CCP. Available at: < https://www.rpo.gov.pl/sites/default/files/Wniosek\%20do\%20TK\%20 owoce $\% 20$ zatrutego $\% 20$ drzewa $\% 20$ art $\% 20$ art.\%20168a\%20\%20KPK\%20 6.05.2016.pdf >. Access on: September 10, 2020. 
of the defendant's cellmates is also allowed despite serious concerns over their use in criminal cases $^{46}$.

Fourthly, every person suspected of a crime has a right to counsel of his or her our choice. Several conditions should be met, however, to apply for a legal aid lawyer. First of all, legal aid is being provided for indigent defendants whose cases fall within the scope of cases for which defence is mandatory. Under Article 79 CCP, a suspect or the person accused of a crime must have defence counsel if he or she is (1) minor, (2) deaf, dumb, or blind, (3) insane, (4) has no command of the Polish language.

The defendant must have a defence counsel when the court deems that necessary because of circumstances impeding the defence. Also, according to Article $80 \mathrm{CCP}$, the person accused of a crime must have defence counsel in proceedings before a Voivodship Court as a court of the first instance if he or she is accused of a felony - the crime with the sentencing limit of more than three years of imprisonment. If the defendant's case does not fall into any of those categories, he or she can receive legal aid on the motion based on indigence under the condition that the lack of means would be "adequately demonstrated" (Article 78 CCP). The law, however, does not specify how an indigent person is to "adequately demonstrate" his or her inability to bear the costs of defence, which often limits the access to legal aid.

It should be noted that some organizational impediments are affecting the exercising of the right to legal counsel in the case of the detained suspects. Often, in police stations, no information on the local criminal lawyers and their contact phone numbers is provided. It also happens that the attorney meets his client for the first time after official charges have been pressed. Needless to say that at this stage, it is usually too late for the lawyer to intervene and prevent the use of questionable interrogation techniques. Besides, the investigative officers are allowed to proceed with the interrogation of detainees without the defence counsel of their choice (Article $301 \mathrm{CCP}$ ). In case-law, there is an opinion that

46 RUSINEK, M. Rozdział 25. Zakazy odnoszące się do sposobu dowodzenia. In: Skorupka, J (editor). System Prawa Karnego Procesowego. Tom VIII. Część 2: Dowody. Warsaw: Wolters Kluwer, p. 2301, 2019. 
evidence obtained as a result of the suspect's interrogation conducted without the presence of a lawyer must be considered admissible unless other circumstances, i. e. the ones listed in Articles 168a and $171 \S 7$ CCP, would undermine its admissibility ${ }^{47}$.

An important guarantee is provided by Article $87 \mathrm{CCP}$, which allows a witness to be represented by the lawyer of his or her choice during the police interview. The presence of a lawyer reduces the likelihood of misconduct on the part of the police. However, under Article $87 \S 3$ $\mathrm{CCP}$, the prosecutor may refuse to allow the lawyer to participate in the proceedings if he deems that the interests of the witness do not require such legal representation. The law does not define the situations where such representation could be unnecessary. In our opinion, this provision contradicts the provisions of Article 6 (3) of the European Convention by favouring the interests of the prosecution. It appears that this tendency to favour the prosecution dominates in the Polish procedural law. Within the current legal framework, defence attorneys have a rather limited possibility to actively participate in preliminary proceedings - the model criticized by many Polish scholars ${ }^{48}$.

\section{Legal SAFEgUARDS AGAinst COERCED CRIMINAL CONFESSIONS IN tHE RUSSIAN FEDERATION}

The Russian Code of Criminal Procedure of $2001^{49}$ (CCP RF) contains several legal protections against coercive police practices. Firstly, according to Article 75 (1) CCP RF, the proof obtained with a violation of the demands of the Code shall be qualified as inadmissible.

47 Judgement of the Polish Supreme Court of 27 June 2017 in the case no. II KK 82/17. Available at: <https://sip.lex.pl/orzeczenia-i-pisma-urzedowe/orzeczenia-sadow/ii-kk-82-17-podstawy-kasacji-rzecznika-praw-522431726>. Access on: September 10, 2020.

48 KULESZA, C. Rozdział 10. Obrońca. In: KULESZA, C. (editor). Tom VI: Strony i inni uczestnicy postępowania karnego. In: HOFMAŃSKI, P. (editor). System Prawa karnego procesowego, Warsaw: Wolters Kluwer, p. 972-973, 2016.

49 Code of Criminal Procedure of the Russian Federation of 18 December 2001. Available at: <https://www.consultant.ru/document/cons_doc_ LAW_34481/>. Access on: September 10, 2020. 
The inadmissible proof is deprived of legal force and cannot serve as a basis for the accusation or be used for proving any of the circumstances relevant to the criminal case. Some scholars suggest that the rule laid down in Article 75 (1) CC RF can be applied only to the evidence which incriminates the defendant. So, evidence obtained in breach of procedural rules may nevertheless be used to prove the defendant's innocence or to establish other facts that could be beneficial for the defence ${ }^{50}$.

The defence can file the motion to exclude evidence based on Article 75 (1) CCP RF either during a preliminary investigation or later during a trial. It may also be filed at any time in upper-tier tribunals. If such a motion is filed during the investigation stage and the public official handling the case allows the motion, a trial court would be unable to assess this evidence. Therefore, scholars argue that, in such a case, there must be the possibility to re-examine the excluded evidence in a courtroom since the law requires criminal judges to evaluate all the evidence collected in the case $\mathrm{e}^{51}$. Others, however, believe that the decision to exclude the illegally obtained evidence made during the initial stages of proceedings should be treated as the final. It can be, however, contested during the trial or even later in an upper tribunal if the prosecution files a respective motion $^{52}$. In practice, the motions on the ground of Article 75 CCP RF are usually filed and examined during a trial.

According to the Supreme Court's guidelines, dealing with exclusionary motions, courts should assess the nature of the rule allegedly violated. However, no criteria have been defined to determine the significance of the violation in question. So, courts have broad discretion in deciding on the admissibility of illegally obtained criminal evidence. The Supreme Court pointed out that there should be one exception.

50 KARJAKIN, E.A. Asimmetrija pravil o dopustimosti dokazatel'stv v ugolovnom sudoproizvodstve kak forma realizacii polozhenija o blagoprijatstvovanii zashhite. Rossijskaja justicija, n. 9, p. 33 - 36, 2017; ISAENKO, V.N. Voprosy dopustimosti dokazatel'stv v materialah sudebnoj praktyki. Ugolovnoe prawo, n. 5, p. 113 - 120, 2017.

51 BALAKSHIN, V.S. Priznanie dokazatel'stv, poluchennyh s narusheniem trebovanij ugolovno-processual'nogo zakona, nedopustimymi i iskljuchenie ih iz ugolovnogo dela. Rossijskij sud'ja, n. 1, p. 38 - 45, 2018.

52 NAUMOV, K.A. Novyj shag zakonodatelja: povysitsja li jeffektivnost' sudebnogo kontrolja i prokurorskogo nadzora? Zakonnost', n. 4, p. 41 - 44, 2017. 
If the evidence was obtained through the violation of the individual rights guaranteed by the Russian Constitution ${ }^{53}$, as would be the case, for example, if the defendant's confession was obtained by the use of torture, inhuman or degrading treatment (the right provided for in Article 21 of the Constitution), it should be declared inadmissible regardless of its content and reliability ${ }^{54}$. This interpretation generally follows the European Court jurisprudence concerning the issue of evidence obtained with the infringement of the rights guaranteed by the Convention. Nevertheless, the information provided by the suspect under torture or another form of coercion is allowed to use in the search for other evidence.

In practice, Russian courts are often prejudiced against the claims concerning improper police compulsion. They tend to apply inadequately high standards of proof even though the use of torture appears to be widespread across the country. In 2019, for example, Russian courts found 641 law enforcement officers guilty of exceeding their powers with the use of violence or special means - the crime penalized under Article 286 of the Russian Criminal Code ${ }^{55}$. The complaints regarding the use of coercive interrogation techniques are usually treated as a typical defence strategy rather than the source of information that needed to be thoroughly checked. Quite often the burden of proof in such cases is incorrectly placed on the defence party ${ }^{56}$.

Article 75 (2) CCP RF provides that inadmissible proof shall be evidence given by the suspect or the person accused of a crime in the

53 Constitution of Russian Federation of 12 December 1993. Available at: < http://www.constitution.ru/10003000/10003000-4.htm > . Access on: September 10, 2020.

54 Guidelines of the Russian Supreme Court concerning the application of the provisions of the Russian Constitution of March 3, 2004. Available at: <http://www.constitution.ru/decisions/10003328/10003328.htm>. Access on: September 10, 2020.

55 Judicial Department at the Supreme Court of the Russian Federation. Statistical data on the courts' decisions in 2019. Available at: < https://www.hrw. org/reports/1999/russia/Russ99o-04.htm>. Access on: September 10, 2020; Human Rights Watch. A persistent pattern of torture and ill-treatment. Available at: < https://www.hrw.org/reports/1999/russia/Russ99o-04.htm>. Access on: September 10, 2020.

56 Overview of the jurisprudence of the Russian Supreme Court of 2018, Bulletin of the Supreme Court of the Russian Federation, n. 1, 2019. 
course of the pretrial proceedings on the criminal case in the absence of the defence counsel, including the cases of the refusal from the council, and not confirmed by the defendant in the court. It should be noted that in Russia all criminal suspects are provided with free legal assistance to guarantee adversarial proceeding. The presence of a lawyer is considered obligatory unless a person implicitly waives his right to an attorney (Article 51 CCP RF). However, even in that case, an investigative officer may insist on the presence of a lawyer to prevent tactically motivated defence motions ${ }^{57}$. If the suspect cannot afford a lawyer, the one would be provided by the state under Article 16 CCP RF. It is also worth noting that a defence attorney has a broad range of procedural rights during the initial stage of the proceedings. Among the most important is the right to conduct parallel investigations including the right to appoint forensic experts and interrogate witnesses (Articles 49, 53, 86 CCP RF).

However, there is a well-known problem with the quality of free legal aid. In such cases, it is not unusual to see the ineffective and inadequate criminal defence. There are several reasons why this happens. First of all, legal aid lawyers are insufficiently paid. Since 2019, a legal aid lawyer is being paid around 2000 rubles per day, which is approximately 23 euros $^{58}$ - a very small sum bearing in mind the rapid inflation of the costs of living in Russia. For many criminal lawyers, this money is the main source of income. Therefore, they take as many cases as possible. The resulting overload concerns many legal practitioners and scholars ${ }^{59}$. More importantly, it is not unusual to see unethical collaboration between legal aid lawyers and police officers. To obtain more cases in the future, some lawyers deliberately ignore the interests of their clients providing erroneous legal advice or simply refusing to offer

57 CHEBOTAREVA, I.N. Otkaz podozrevaemogo, obvinjaemogo ot naznachennogo zashhitnika: pravovye pozicii Konstitucionnogo Suda RF. Advokatskaja praktika, n. 6, p. $28-32,2019$.

58 Governmental Decree on the fees paid to legal aid lawyers of December 1, 2012. Available at: <https://www.consultant.ru/document/cons_doc_ LAW_138571/ >. Access on: September 10, 2020.

59 SEREDNEV, V. A. K voprosu nekotoryh pričin profanacii advokatskoj deatelnosti v otecestvennom ugolovnom processe. Advokatskaa praktika, n. 3, p. 3944, 2019; KURCHENKO, V. N. Obespecenie obvinaemomu prava na zasitu: interpretacia v sudebnoj praktike. Ugolovnoe parvo, n. 1, p. 89-95, 2019. 
any useful legal information which could help their clients to select the most effective defence strategy. Unfortunately, all complaints regarding such unethical and highly questionable behaviour end up in the local bar associations, which place the burden of proof on the claimants and often favour their members ${ }^{60}$.

Another shortcoming relates to the fact that the exclusionary rules provided for in Article 75 CCP RF do not apply to police questioning, which often takes place before an official procedural interrogation. It should be noted, however, that most complaints about police alleged misconduct concern the suspect's contacts with the police officers outside the interrogation room.

Under Article 56 CCP RF, each person suspected of committing a crime has the right to legal assistance. The investigative officers are obliged to respect this right regardless of the case circumstances and the objectives of the interrogation. If such a witness insists on the presence of a lawyer, his or her questioning should be postponed until the selected lawyer arrives. The presence of a lawyer is of particular importance in the criminal cases concerning white-collar crime where criminal suspects often maintain the status of a witness during the initial stage of the investigation. According to Article 189 CCP RF, the witness's lawyer has the right to be present throughout the interview, to ask questions and object to the questions being asked, to advice his client any time during the interview, to add remarks and objections to the interrogation written report. These provisions comply with the European Court jurisprudence regarding the legal status of the person whom the domestic authorities suspected to be involved in a criminal offence. The state, however, does not provide free legal aid in such cases.

It should be noted that under Article 191 CCP RF a child under sixteen years of age shall be interviewed in the presence of his parent or guardian unless it is against the best interests of the child. The fact that adolescent suspects are interrogated in the presence of an allied adult is very important. In 2013 the provisions of Article 45 CCP RF were amended allowing the child's legal representatives to apply for a legal

60 FRANCIFOROVA, S. Ju. Pravovye garantii dejatel'nosti advokata v ugolovnom sudoproizvodstve. Advo-katskaja praktika, n. 5, p. 14 - 18, 2019. 
aid lawyer. This provision provides extra protection to this especially vulnerable group of case participants. The rule of Article $45 \mathrm{CCP}$ RF appears to be outside the scope of the Member States' obligations arising from the jurisprudence of the European Court. There is, however, no official data on the number of criminal cases where such assistance have been provided.

Unlike in Poland, the law does not forbid the substitution of the testimony of the accused with notes, personal diaries or other secondary sources of information. In case-law, however, one can find an important exception. In 2012, the Russian Supreme Court held that the testimony of investigative officers regarding the content of suspect's confession obtained without the presence of a lawyer should be considered inadmissible under Article 75 (2) CCP RF ${ }^{61}$. Nevertheless, Russian courts allow using jailhouse informant testimony - another highly controversial and unreliable source of secondary confessions.

Secondly, the law restricts the length of procedural interviews and interrogations. Under Article $187 \mathrm{CCP}$ RF, interviews and interrogations shall not be conducted for more than four hours without a break and more than eight hours a day. In the case of minors, there are even shorter timeframes - a child under the age of seven years can be questioned for no more than thirty minutes without a break and no more than one hour daily, a child under the age of fourteen years can be questioned for no more than two hours without a break and for no more than four hours a day. There are no legal remedies against the investigative officers violating these requirements. The defence, however, could try to exclude confession on the ground of Article 75 (1) CCP RF or suggest that regarding the circumstances of the case lengthy interrogations compromise the reliability of the evidence.

Thirdly, under Article 173 CCP RF, a repeated interrogation of the accused on the same charge, if he has previously refused to give testimony at the first interrogation, may be conducted only at the request of the accused himself. This rule refers to the general principle that

${ }^{61}$ Judgement of the Russian Supreme Court of 6 March 2016 in the case no. 70-O12-3. Available at: <http://base.garant.ru/70310476/> . Access on: September 10, 2020. 
no one shall be compelled to be a witness against himself ${ }^{62}$. It also provides an important guarantee against the use of this type of coercive interrogation techniques.

Fourthly, a special investigative procedure called "verification of the evidence on the spot" was introduced in 2001. According to Article 194 CCP RF, the evidence, given at an earlier date by the suspect or by the accused, as well as by the victim or by the witness, may be verified or specified at the place connected with the investigated event. This procedure aims into establishing "the new circumstances of importance for the criminal case" - the provision preventing investigative officers from duplicating testimonial evidence by simply re-enacting the suspect's previous interrogation on the spot. Importantly, Article 194 CCP RF contains several well-known forensic recommendations regarding the verification of testimonial evidence:

- the verification on the spot shall amount to the procedure, during which the suspect reproduces the situation and the circumstances of the investigated event, points out the objects, the documents and the traces of importance for the criminal case, and demonstrates certain actions;

- any outside interference with the process of verification or any leading questions as well as a simultaneous verification of the testimonies of several persons would be inadmissible;

- the verification of the evidence shall be started with the suggestion that the suspect shows the place where his evidence is going to be verified;

- only after the suspect freely tells the story and demonstrates the actions, he or she may be asked questions.

Besides, during the verification of evidence on a spot, there should be at least two attesting witnesses with no interest in the outcome of the case who certify the fact of the procedure having been conducted, as well as its results. If due to some reasons the participation of attesting witnesses is impossible, investigative officers should apply technical devices to document the process of verification and its results. The law also requires the presence of the suspect's attorney during the procedure

${ }^{62}$ DZHABIROV, A. Bezmolvnoe priznanie, ili Molchat mozno po-raznomu. Ez Jurist, n. 13, p. 8, 2016. 
(Article 53 CCP RF). It is worth noting that the provisions of Article 194 CCP RF do not exclude the possibility of staging the spot by adding some new objects or removing original objects to check the suspect ability to identify these inconsistencies ${ }^{63}$.

Fifthly, under Article 77 (2) CCP RF, the admission by the accused of his guilt in committing the crime can serve as the foundation for the charge only if his guilt is confirmed by the aggregate of the proof, existing on the criminal case. This provision refers to the idea that each evidence, especially suspect's confession, must be cross-checked with other pieces of evidence collected in the case ${ }^{64}$. The practical importance of Article 77 (2) CCP RF is, however, rather limited. It is very unlikely that the prosecution case would be based solely on uncorroborated confession.

\section{Discussion}

The discussion over police-elicited criminal confessions often amounts to the determination whether the police, or in broader terms, law enforcement authorities must be endowed with broad discretionary power to heir authority to effectively address current challenges, or instead, individual rights and privileges should be favoured over public interests. In this oversimplified approach, the answer may seem to be obvious: choosing between individual rights and investigative effectiveness, many would probably opt for the latter. However, in the light of the European Convention and the jurisprudence of the European Court, all states are required, although not in expressed terms, to adopt pertinent legal safeguards, including the exclusionary evidence rules ${ }^{65}$. In the case of Poland, the provisions concerning the admissibility of illegally

63 BAEV, O.; SOLODOV, D. Proizvodstvo sledstvennyh dejstvij: kriminalisticheskij analiz UPK Rossii, praktika, rekomendacii. Moscow: Eksmo, p. 157-158, 2010.

64 SOLOVIEVA, N. A.; PEREKRESTOV, V. N. Dokazatelstvennaâ funkcia priznania. Rossijskaa usticia, n. 11, p. 13-18, 2008; KORNAKOVA, S. V. Nekotorye suzhdenija o nesovershenstve norm upk rf, kasajushhihsja priznanija viny obvinjaemym. Sibirskie ugolovno-processual'nye i kriminalisticheskie chtenija, n. 4 (26), p. 113, 2019.

65 HO, H.L. The Fair Trial Rationale for Excluding Wrongfully Obtained Evidence. In: GLESS S., RICHTER T. (editors). Do Exclusionary Rules Ensure 
obtained evidence, i.e. Article 168a, 171 CCP, can be interpreted in different ways. The lack of a unified interpretation of those provisions remains an issue of serious concern in relation to legal certainty and transparency. In Russia, broad discretion is conferred on the national courts in determining whether the violation in question is significant enough to exclude the resulting evidence. It allows courts to decide on the admissibility of evidence on a case-by-case basis - the model that appears to be optimal, given the uniqueness of each case. However, the lack of clear formal criteria results in the absence of a unified practice and legal certainty.

Another common shortcoming relates to the scope of exclusionary rules provided for in national law. An official interrogation is often preceded by unofficial police questioning. In Russia, police officers are not required to document the process and the results of police questioning. In Poland, a police officer is obliged to produce an official written note. However, such a note contains a subjective assessment of the facts and often lacks significant details of the events. Without accurate and proper documentation, it is difficult to establish the facts related to alleged police misconduct. Besides, in both countries, the evidence derived from evidence obtained in violation of the defendant's conventional and constitutional rights could be legally used against the defendant.

On the positive side is the fact that in both countries evidence obtained in violation of the rights provided by Article 3 of the European Convention is considered inadmissible regardless of the circumstances of the case, thus, following the European Court jurisprudence. Nevertheless, national courts tend to treat the allegations regarding the use of improper investigative techniques as a defence strategy. While it may be true in some cases, it is still a quite dangerous generalization. It places the burden of proof, which is usually critical for the outcome of the case, on the defence party. Judicial inquiries into the allegations concerning police misconduct are often done by formal and ineffective measures. It should be, however, acknowledged that in such cases there is usually limited evidence. In both countries, it is possible and legal to document

a Fair Trial? Ius Gentium: Comparative Perspectives on Law and Justice, v. 74, p. 283-305, 2019. 
procedural interrogations by using only written reports. In many cases regarding the alleged use of inappropriate investigative techniques, such reports are the only source of information about what happened during the interrogation and the statements made by the suspect. Besides, the interrogator' written report is always a mediated account of the interrogation, which does not accurately preserve the substance of the questions asked and the statements made. We suggest that the issue should be addressed by introducing additional means of documentation. Videotaping during procedural interrogations, as well as police questioning, should become mandatory. Our experience shows, however, that despite many obvious benefits, videotaping interrogations may raise new challenges. It is not unusual for the suspect's interrogations to last several hours and there is rarely, if ever, only one such an interrogation. So, the analysis of the resulting records is often a demanding and timeconsuming task for both the defence and later for the trial court. In our opinion, written records should be maintained alongside videotapes to provide a brief overview of the suspect's testimony. We also suggest introducing obligatory medical examinations of the suspect after police questioning and interrogations.

Regarding other legal safeguards, we doubt whether the detailed provisions concerning the length of interrogations, the prohibition of repeated interrogations and the confession evidentiary value overweight more general rules provided by the Polish law (Article 171 CCP). Instead, the growing number of applications concerning the violations of Article 3 and 6 of the Convention against the Russian Federation ${ }^{66}$ may suggest otherwise. The more important issue in terms of the prevention of improper police compulsion is the implementation of the right to assistance of a defence counsel. The practice where the defendant meets his lawyer at the end of the investigation is highly questionable concerning the European Court jurisprudence. On the other hand, it is crucial to provide not only readily available but quality legal assistance.

${ }_{66}$ European Court of Human Rights. Analysis of statistics 2019. Available at: < https://www.echr.coe.int/Documents/Stats_analysis_2019_ENG.pdf/> . Access on: September 10, 2020. 


\section{Conclusions}

1. There is no doubt that exclusionary rules are an important guarantee of the conventional right to the due process. The jurisprudence of the European Court following the provisions of Article 6 the Convention obliges all states to adopt such rules to provide a sufficient level of protection. However, the vague wording of pertinent legal provisions might be the factor impinging on their efficiency.

2. The allegation regarding improperly compelled criminal confessions should gain more attention from the national courts, as the jurisprudence of the European Court requires. To address the problem of the judicial formalism in assessing this type of claims, we suggest introducing mandatory video recording of all interrogations and police questioning, as well as obligatory medical examinations of the suspect.

3. In the case of Russia, the issue regarding the quality of free legal assistance should be addressed more effectively. It is crucial to provide qualified legal assistance to the suspect regardless of their financial status. In the case of Poland, the question of whether there should be much broader access to legal assistance at the early stages of criminal proceedings can not be answered conclusively since the law significantly limits the rights of defence attorneys.

4. We suggest that the way criminal investigators verify a confession is equally important. Practice shows that, when dealing with criminal confessions, the verification of suspect testimony on a spot could provide valuable clues as to whether the confession is authentic or not. We believe that certain organizational aspects of this quite complex investigative procedure should not be left within the discretion of the investigative officers. The detail provisions of Article 194 CCP RF regarding the verification of evidence on a spot could be used as a reference model.

\section{REFERENCES}

2019 Commission report on monitoring the application of EU law. Available at: $<$ https://ec.europa.eu/info/publications/2019-commission-report-monitoringapplication-eu-law_en >. Accessed on: September 10, 2020. 
Appeal of the Polish Ombudsman regarding Article 168a CCP. Available at: < https://www.rpo.gov.pl/sites/default/files/Wniosek\%20do\%20TK\%20owoce\%20 zatrutego\%20drzewa\%20art\%20art.\%20168a\%20\%20KPK\%206.05.2016.pdf >. Access on: September 10, 2020.

BAEV, O.; SOLODOV, D. Proizvodstvo sledstvennyh dejstvij: kriminalisticheskij analiz UPK Rossii, praktika, rekomendacii. Moscow: Eksmo, 2010.

BALAKSHIN, V.S. Priznanie dokazatel'stv, poluchennyh s narusheniem trebovanij ugolovno-processual'nogo zakona, nedopustimymi i iskljuchenie ih iz ugolovnogo dela. Rossijskij sud'ja, n. 1, p. $38-45,2018$.

BŁOŃSKI, M. Przeprowadzanie na rozprawie dowodów uzyskanych w ramach czynności operacyjno-rozpoznawczych. Prokuratura i prawo, n. 9, p.78-92, 2017.

BRZOZOWSKI, Sebastian. Dopuszczalność dowodu w kontekście regulacji art. 168a k.p.k. Przegląd Sądowy, n. 10, p. 60-74, 2016.

CHEBOTAREVA, I.N. Otkaz podozrevaemogo, obvinjaemogo ot naznachennogo zashhitnika: pravovye pozicii Konstitucionnogo Suda RF. Advokatskaja praktika, n. 6 , p. $27-35,2019$.

Code of Criminal Procedure of the Republic of Poland of 6 June 1997. Available at: <https://isap.sejm.gov.pl/isap.nsf/download.xsp/WDU19970890555/U/ D19970555Lj.pdf>. Access on: September 10, 2020.

Code of Criminal Procedure of the Russian Federation of 18 December 182001. Available at: <https://www.consultant.ru/document/cons_doc_LAW_34481/>. Access on: September 10, 2020.

Convention against Torture and Other Cruel, Inhuman or Degrading Treatment or Punishment of 1984, Available at: < https://treaties.un.org/doc/ Treaties/1987/06/19870626\%2002-38\%20AM/Ch_IV_9p.pdf >. Access on: September 10, 2020.

Directive (EU) 2016/343 of the European Parliament and of the Council of 9 March 2016 on the strengthening of certain aspects of the presumption of innocence and of the right to be present at the trial in criminal proceedings. Available at: <https:// eur-lex.europa.eu/legal-content/EN/TXT/?uri=CELEX\%3A32016L0343>. Access on: September 10, 2020.

Directive (EU) 2016/800 of 11 May 2016 on procedural safeguards for children who are suspects or accused persons in criminal proceedings, Available at: < https://eur-lex.europa.eu/legal-content/EN/TXT/?uri=CELEX\%3A32016L0800>. Access on: September 10, 2020. 
Directive 2012/13/EU of 22 May 2012 on the right to information in criminal proceedings. Available at: < https://eur-lex.europa.eu/legal-content/EN/ TXT/?uri=celex:32012L0013>. Access on: September 10, 2020.

Directive 2013/48/EU of 22 October 2013 on the right of access to a lawyer in criminal proceedings. Available at: <https://eur-lex.europa.eu/legal-content/EN/ TXT/?uri=celex\%3A32013L0048 >. Access on: September 10, 2020.

DZHABIROV, A. Bezmolvnoe priznanie, ili Molchat mozno po-raznomu. Ez Jurist, n. 13, p. 6-11, 2016.

EECHAUDT, V., CLAEYS, J., BEKEN, T. V.; CIUFFOLETTI, S.; HUGUES DE SUREMAIN, RANAL, D. Research project EUPRETRIALRIGHTS Improving the protection of fundamental rights and access to legal aid for remand prisoners in the European Union. Analysis of European law as regard to access of detained persons to the law and to court. Available at: <https://biblio.ugent.be/publication/8625571/ file/8625572>. Access on: September 10, 2020.

European Convention on Human Rights and Fundamental Freedoms of 1950, Available at: <https://www.echr.coe.int/Documents/Convention_ENG.pdf >. Access on: September 10, 2020.

European Court of Human Rights. Analysis of statistics 2019. Available at: < https://www.echr.coe.int/Documents/Stats_analysis_2019_ENG.pdf/> . Access on: September 10, 2020.

European Court of Human Rights. Guide on Article 6 of the European Convention on Human Rights Right to a fair trial (criminal limb). Updated on 30 April 2020, p. 75. Available at: $<$ https://www.echr.coe.int/Documents/Guide_Art_6_criminal_ ENG.pdf >. Access on: September 10, 2020.

European Court of Human Rights. Guide on Article 6 of the European Convention on Human Rights. Right to a fair trial (criminal limb). Updated on 30 April 2020, p. 36. Available at: $<$ https://www.echr.coe.int/Documents/Guide_Art_6_criminal_ ENG.pdf $>$. Access on: September 10, 2020.

European Court of Human Rights. Guide on Article 6 of the European Convention on Human Rights Right to a fair trial (criminal limb). Updated on 30 April 2020, p. 38-39. Available at: <https://www.echr.coe.int/Documents/Guide_Art_6_ criminal_ENG.pdf >. Access on: September 10, 2020.

European Court of Human Rights. Judgement in the case of Affaire Urazbayev v. Russia of 8 October 2019. Application no. 13128/06. Available at: <http://hudoc. echr.coe.int/eng?i=001-196408>. Access on: September 10, 2020. 
European Court of Human Rights. Judgement in the case of case of Almaši v. Serbia of 8 October 2019. Application no. 21388/15. Available at: <http://hudoc. echr.coe.int/eng?i=001-196417>. Access on: September 10, 2020.

European Court of Human Rights. Judgement in the case of El Haski v. Belgium of 25 September 2012. Application no. 649/08. Available at: <https://hudoc.echr.coe. int/fre\#\{\%22itemid\%22:[\%22001-113445\%22]\}>. Access on: September 10, 2020.

European Court of Human Rights. Judgement in the case of Ibrahim and others v. the United Kingdom of 16 December 2014. Applications nos. 50541/08, 50571/08, 50573/08 and 40351/09. Available at: < http://hudoc.echr.coe.int/ fre?i=001-148676>. Access on: September 10, 2020.

European Court of Human Rights. Judgement of the Grand Chamber in the case of John Murray v. the United Kingdom of 8 February 1996. Application no. 18731/91. Available at: <https://hudoc.echr.coe.int/eng\# \{\%22dmdocnumber\%22:[\%22695857\%22],\%22itemid\%22:[\%22001-57980\%22]\}>. Access on: September 10, 2020.

European Court of Human Rights. Judgement of the Grand Chamber in the case of Gäfgen v. Germany of 1 June 2010. Application no. 22978/05. Available at: < https://hudoc.echr.coe.int/tur\#\{\%22itemid\%22:[\%22001-99015\%22]\} >. Access on: September 10, 2020.

European Court of Human Rights. Judgement of the Grand Chamber in the case of Simeonovi v. Bulgaria of 12 May 2017. Application no. 21980/04. Available at: < http://hudoc.echr.coe.int/eng?i=001-172963>. Access on: September 10, 2020.

European Court of Human Rights. Judgement of the Grand Chamber in the case of Beuze v. Belgium of 9 November 2018. Application no. 71409/10. Available at: < http://hudoc.echr.coe.int/eng?i=001-187802>. Access on: September 10, 2020.

FRANCIFOROVA, S. Ju. Pravovye garantii dejatel'nosti advokata v ugolovnom sudoproizvodstve. Advokatskaja praktika, n. 5, p. 14 - 18, 2019.

GABERLE, A. Dowody w sądowym procesie karnym, Kraków: Wolters Kluwer, 2007.

GORA, Ł. Aksjologia procesowa a dopuszczalność dowodu z art. 168a k.p.k. Państwo i Prawo, n. 10, p. 131-132, 2018.

Governmental Decree on the fees paid to legal aid lawyers of December 1, 2012. Available at: <https://www.consultant.ru/document/cons_doc_LAW_138571/ >. Access on: September 10, 2020. 
GRUZA, Ewa; GOC, Mieczysław, MOSZCZYNSKI, Jarosław. Kryminalistyka, czyli o współczesnych metodach dowodzenia przestępstw. Zagadnienia prawne. Warsaw: Wolters Kluwer, 2020.

GUDJONSSON, Gisli H. The Psychology of Interrogations and Confessions: A handbook. Chichester: John Wiley \& Sons Ltd, 2003.

GUDJONSSON, Gisli H.; PEARSE, John. Suspect Interviews and False Confessions. Current Directions in Psychological Science, v. 20, n. 1, p. 33-37, 2011. https://doi. org/10.1177\%2F0963721410396824

Guidelines of the Russian Supreme Court concerning the application of the provisions of the Russian Constitution of March 3, 2004. Available at: <http:// www.constitution.ru/decisions/10003328/10003328.htm>. Access on: September 10, 2020.

HO, H.L. The Fair Trial Rationale for Excluding Wrongfully Obtained Evidence. In: GLESS S., RICHTER T. (editors). Do Exclusionary Rules Ensure a Fair Trial? Ius Gentium: Comparative Perspectives on Law and Justice, v. 74, p. 283-305, 2019.

HODGSON, J. The Challenge of Universal Norms: Securing Effective Defence Rights Across Different Jurisdictions and Legal Cultures. Journal of Law and Society, 46, p. 95-114, 2019. https://doi.org/10.1111/jols.12185

Human Rights Watch. A persistent pattern of torture and ill-treatment. Available at: < https://www.hrw.org/reports/1999/russia/Russ99o-04.htm>. Access on: September 10, 2020.

Human Rights Watch. World Report 2020, Available at: <https://www.hrw.org/ sites/default/files/world_report_download/hrw_world_report_2020_0.pdf $>$. Access on: September 10, 2020.

ISAENKO, V.N. Voprosy dopustimosti dokazatel'stv v materialah sudebnoj praktyki. Ugolovnoe prawo, n. 5, p. 113 - 120, 2017.

JASIŃSKI, W. Racjonalna regulacja karnoprocesowej dopuszczalności dowodów uzyskanych z naruszeniem praw jednostki. Acta Universitatis Wratislaviensis, $\mathrm{n}$. 3978, p. 83-95, 2020. https://doi.org/10.19195/0137-1134.120.54

JASIŃSKI, W. Rozdział 26. Zasady wykorzystywania dowodów. In: HOFMAŃSKI, P., SKORUPKA J. (editors). System Prawa Karnego Procesowego. Tom VIII: Dowody. Part 2, Warszawa: LexisNexis, p. 2668-2669, 2019.

Judgement of the Appellate Court in Gdansk of 22 June 2016 in the case no. II AKa 150/16. Available at: < https://sip.lex.pl/orzeczenia-i-pisma-urzedowe/ 
orzeczenia-sadow/ii-aka-150-16-ustalanie-przez-sad-prawidlowosci-522177843>. Access on: September 10, 2020.

Judgement of the Appellate Court in Poznan of 17 June 2014 in the case no. II AKa 107/14. Available at: <https://sip.lex.pl/orzeczenia-i-pisma-urzedowe/orzeczeniasadow/ii-aka-107-14-prowadzenie-przed-przesluchaniem-rozmowy-521587565 >. Access on: September 10, 2020.

Judgement of the Appellate Court in Warsaw of 9 October 2017 in the case no. II AKa 310/17. Available at: <https://sip.lex.pl/orzeczenia-i-pisma-urzedowe/ orzeczenia-sadow/ii-aka-310-17-wplywanie-na-wypowiedzi-osoby-522498318>. Access on: September 10, 2020.

Judgement of the District Court in Czestochowa of 8 May 2019 in the case no. VII Ka 58/19. Available at: < https://sip.lex.pl/orzeczenia-i-pisma-urzedowe/orzeczeniasadow/vii-ka-58-19-wyrok-sadu-okregowego-w-czestochowie-522761214>. Access on: September 10, 2020.

Judgement of the Polish Supreme Court of 26 June 2019 in the case no. IV KK 328/18. Available at: <http://www.sn.pl/sites/orzecznictwo/Orzeczenia3/IV\%20 KK\%20328-18.pdf>. Access on: September 10, 2020.

Judgement of the Polish Supreme Court of 27 June 2017 in the case no. II KK 82/17. Available at: <https://sip.lex.pl/orzeczenia-i-pisma-urzedowe/orzeczeniasadow/ii-kk-82-17-podstawy-kasacji-rzecznika-praw-522431726>. Access on: September 10, 2020.

Judgement of the Polish Supreme Court of 9 October 2019 in the case no. II KK 500/18. Available at: < https://sip.lex.pl/orzeczenia-i-pisma-urzedowe/ orzeczenia-sadow/v-kk-500-18-postanowienie-sadu-najwyzszego-523102815>. Access on: September 10, 2020.

Judgement of the Russian Supreme Court of 6 March 2016 in the case no. 70O12-3. Available at: <http://base.garant.ru/70310476/> . Access on: September $10,2020$.

Judicial Department at the Supreme Court of the Russian Federation. Statistical data on the courts' decisions in 2019. Available at: < https://www.hrw.org/ reports/1999/russia/Russ990-04.htm>. Access on: September 10, 2020.

KARJAKIN, E.A. Asimmetrija pravil o dopustimosti dokazatel'stv v ugolovnom sudoproizvodstve kak forma realizacii polozhenija o blagoprijatstvovanii zashhite. Rossijskaja justicija, n. 9, p. 33 - 36, 2017. 
KASSIN, S. M.; DRIZIN, S. A.; GRISSO, T.; GUDJONSSON, G. H.; LEO, R. A.; REDLICH, A. D. Police-Induced Confessions: Risk Factors and Recommendations. Law and Human Behaviour, n. 34, p. 16-19, 2010.

KASSIN, Saul M.; GUDJONSSON, Gisli H. The Psychology of Confessions: A Review of the Literature and Issues. Psychological Science in the Public Interest, v. 5, n. 2, p. 33-67, 2004.

KMIECIK, R. Zakazy dowodowe - pojęcie i ich klasyfikacja. Skutki procesowe naruszenia zakazów, reguł i gwarancji procesowych w postępowaniu dowodowym. In: KMIECIK, R.(editor). Prawo dowodowe. Zarys wykładu, Warszawa: Wolters Kluwer, 2008.

KORNAKOVA, S. V. Nekotorye suzhdenija o nesovershenstve norm upk rf, kasajushhihsja priznanija viny obvinjaemym. Sibirskie ugolovno-processual'nye $i$ kriminalisticheskie chtenija, n. 4 (26), p. 110-118, 2019.

KUCHARCZYK, Mariusz. Zakaz substytuowania dowodu z wyjaśnień oskarżonego treścią pism, zapisków i notatek urzędowych. Prokuratura i Prawo, n. 5, p. 137148, 2005.

KULESZA, C. Rozdział 10. Obrońca. In: KULESZA, C. (editor). Tom VI: Strony i inni uczestnicy postępowania karnego. In: HOFMAŃSKI, P. (editor). System Prawa karnego procesowego, Warsaw: Wolters Kluwer, p. 862-975, 2016.

KURCHENKO, V. N. Obespecenie obvinaemomu prava na zasitu: interpretacia $\mathrm{v}$ sudebnoj praktike. Ugolovnoe parvo, n. 1, p. 89-95, 2019.

LEO, R. Police Interrogations, False Confessions, and Alleged Child Abuse Cases. University of Michigan Journal of Law Reform, n. 50, p. 693-721, 2017.

LIPIŃSKI, Konrad. Klauzula uadekwatniająca przesłanki niedopuszczalności dowodu w postępowaniu karnym (art. 168a k.p.k.). Prokuratura i prawo, n. 11, p. 44-59, 2016.

MCCONVILLE, Michael; BALDWIN, John. The role of interrogation in crime discovery and conviction. The British Journal of Criminology, v. 22, n. 2, p. 165 -175, 1982. https://doi.org/10.1093/oxfordjournals.bjc.a047296

MOSCATELLI, Lívia Yuen Ngan. Considerações sobre a confssão e o método Reid aplicado na investgação criminal. Revista Brasileira de Direito Processual Penal, v. 6, n. 1, p. 361-394, 2020. https://doi.org/10.22197/rbdpp.v6i1.331

NAUMOV, K.A. Novyj shag zakonodatelja: povysitsja li jeffektivnost' sudebnogo kontrolja i prokurorskogo nadzora? Zakonnost', n. 4, p. 41 - 47, 2017. 
Overview of the jurisprudence of the Russian Supreme Court of 2018, Bulletin of the Supreme Court of the Russian Federation, n. 1, 2019.

RASSIN, Eric; ISRAËLS, Han. False confessions in the lab: a review. Erasmus Law Review, v. 7, n. 4, p. 219-224, 2014.

RUDICH, V.V., Standarty dopustimosti dokazatel'stv po ugolovnym delam, vyrabotannye v reshenijah Evropejskogo suda po pravam cheloveka. Mezhdunarodnoe ugolovnoe pravo i mezhdunarodnaja justicija, n. 5, p. 9-12, 2017.

RUSINEK, M. Rozdział 25. Zakazy odnoszące się do sposobu dowodzenia. In: Skorupka, J (editor). System Prawa Karnego Procesowego. Tom VIII. Część 2: Dowody. Warsaw: Wolters Kluwer, p. 1982-1995, 2019.

RUSSANO, Melissa B.; MEISSNER, Christian A.; NARCHET, Fadia M.; KASSIN, Saul M. Investigating True and False Confessions Within a Novel Experimental Paradigm. Psychological Science, n. 16(6), p. 481-486, 2015.

SEREDNEV, V. A. K voprosu nekotoryh pričin profanacii advokatskoj deatelnosti v otecestvennom ugolovnom processe. Advokatskaa praktika, n. 3, p. 39-44, 2019.

SKORUPKA, J. Prokonstytucyjna wykładnia przepisów prawa dowodowego w procesie karnym. In: GRZEGORCZYK, T.; OLSZEWSKI R. (editors). Verba volant, scripta manent. Proces karny, prawo karne skarbowe i prawo wykroczeń po zmianach z lat 2015-2016. Księga pamiątkowa poświęcona Profesor Monice Zbrojewskiej, Warszawa: Wolters Kluwer, p. 351-364, 2016.

SKORUPKA, J. Wykorzystanie w postępowaniu karnym dowodów bezpośrednio i pośrednio legalnych. In: GODYŃ, J.; HUDZIK, M.; PAPRZYCKI, L. K. (editors). Zagadnienia prawa dowodowego. Warszawa: Sąd Najwyższy, p. 29-30, 2011.

SOLOVIEVA, N. A.; PEREKRESTOV, V. N. Dokazatelstvennaâ funkcia priznania. Rossijskaa usticia, n. 11, p. 13-18, 2008.

Universal Declaration of Human Rights of 1948. Available at: <https://www. un.org/en/universal-declaration-human-rights/>. Access on: September 10, 2020.

WĄSEK-WIADEREK, Małgorzata. Przegląd orzecznictwa Europejskiego dotyczącego spraw karnych. Zeszyt, n. 1-2, p.21, 2010.

ŻBIKOWSKA, M. Dowód pośrednio nielegalny w polskim procesie karnym. Wojskowy Przegląd Prawniczy, n.1-2, p. 108-124, 2012. 


\section{Additional information and author's declarations (scientific integrity)}

Declaração de conflito de interesses (conflict of interest declaration): the authors confirm that there are no conflicts of interest in conducting this research and writing this article.

Declaração de autoria e especificação das contribuições (declaration of authorship): all and only researchers who comply the authorship requirements of this article are listed as authors; all coauthors are fully responsible for this work in its entirety.

- Denis Solodov: conceptualization, methodology, data curation, investigation, writing - original draft, validation, writing review and editing, final version approval.

- Ilia Solodov: conceptualization, methodology, data curation, investigation, writing - original draft, validation, writing review and editing, final version approval.

Declaração de ineditismo e originalidade (declaration of originality): the authors assure that the text here published has not been previously published in any other resource and that future republication will only take place with the express indication of the reference of this original publication; they also attest that there is no third party plagiarism or self-plagiarism. 
Dados do processo editorial

(http://www.ibraspp.com.br/revista/index.php/RBDPP/about/editorialPolicies)

- Recebido em: 20/04/2020

Equipe editorial envolvida

- Controle preliminar e verificação de plágio: 08/06/2020

- Avaliação 1: 24/06/2020

- Editor-chefe: 1 (VGV)

- Revisores: 3

- Avaliação 2: 07/07/2020

- Avaliação 3: 20/07/2020

- Decisão editorial preliminar: 30/07/2020

- Retorno rodada de correções 1: 10/09/2020

- Decisão editorial 2: 15/09/2020

- Retorno rodada de correções 2: 16/09/2020

- Decisão editorial final: 16/09/2020

\section{COMO CITAR ESTE ARTIGO:}

SOLODOV, Denis; SOLODOV, Ilia. Legal safeguards against involuntary criminal confessions in Poland and Russia. Revista Brasileira de Direito Processual Penal, Porto Alegre, vol. 6, n. 3, p. 1661-1698, set./dez. 2020. https://doi.org/10.22197/rbdpp.v6i3.368

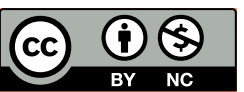

Esta obra está licenciada com uma Licença Creative Commons Atribuição-NãoComercial 4.0 Internacional. 